\title{
Rice co-products in pig feed during the starter phase (15 to $30 \mathrm{~kg}$ )
}

\section{Coprodutos do arroz na alimentação de suínos na fase inicial (15 a $30 \mathrm{~kg}$ )}

\author{
Paulo Levi de Oliveira Carvalho'*; Clodoaldo de Lima Costa Filho'; \\ Liliane Maria Piano Gonçalves ${ }^{3}$; Tiago Junior Pasquetti ${ }^{4}$; Dani Perondis; \\ Laura Marcela Diaz Huepa ${ }^{3}$; Lina María Peñuela-Sierra ${ }^{6}$; Aparecida da Costa \\ Oliveira $^{7}$; Silvana Teixeira Carvalho ${ }^{8}$; Jansller Luiz Genova ${ }^{9}$
}

\begin{abstract}
This study was carried out to evaluate the inclusion of two rice co-products in pig feed during the starter phase in terms of the nutritional value and digestibility of the co-products, and the effect on plasma parameters, growth performance and economic viability. In Experiment I, a digestibility assay was performed using 30 barrows ( $14.4 \pm 2.4 \mathrm{~kg}$ body weight), which were distributed in a completely randomised design. The co-products studied were broken rice (BR) and hominy rice $3 / 4(\mathrm{HR})$ to replace the reference diet $(300 \mathrm{~g} / \mathrm{kg})$. The estimated digestible energy (DE) and metabolisable energy (ME) were 3,476 and 3,360 kcal/ $\mathrm{kg}$ for BR and 3,487 and 3,362 kcal/kg for HR, respectively. In Experiment II, 108 pigs ( $15.5 \pm 1.0$ to $30.1 \pm 1.3 \mathrm{~kg}$ body weight) were used, distributed in a randomised block design with a factorial analysis scheme $(2 \times 4)$, using two types of rice and four inclusion levels (160, 320,480 , and $640 \mathrm{~g} / \mathrm{kg}$ ), with six replicates and two pigs per experimental unit. Additionally, a control diet was used with no inclusion of the co-product. The daily weight gain increased and the feed:gain (F:G) ratio decreased as HR content of feed increased. An effect of both types of rice on plasma glucose concentration was obtained, in which the pigs fed with BR showed the highest values. The cost of diet per kilogram of body weight gain increased as BR levels in the diet increased. It was observed that inclusion levels of 480 and $640 \mathrm{~g} / \mathrm{kg}$ of BR differed from the control diet, showing the highest costs. HR and BR can be used in pig feed in the starter phase at up to $640 \mathrm{~g} / \mathrm{kg}$ without impairing performance.
\end{abstract}

Key words: Co-product. Digestibility. Growth performance. Pigs.

\section{Resumo}

Este estudo foi realizado para avaliar a inclusão de dois coprodutos do arroz na alimentação de suínos durante a fase inicial sobre o valor nutricional e a digestibilidade dos coprodutos, parâmetros

\footnotetext{
1 Prof., Universidade Estadual do Oeste do Paraná, UNIOESTE, Marechal Cândido Rondon, PR, Brasil. E-mail: paulolevi@ yahoo.com.br

2 Graduado em Zootecnia, Universidade Estadual de Maringá, UEM, Maringá, PR, Brasil. E-mail: bobzootecnia@hotmail.com

3 Drs. em Zootecnia, Universidade Estadual de Maringá, UEM, Maringá, PR, Brasil. E-mail: liliane_piano@hotmail.com; lemondedelaura28@hotmail.com

4 Prof., Universidade Estadual do Mato Grosso do Sul, UEMS, Aquidauana, MS, Brasil. E-mail: pasquettizoo@yahoo.com.br

5 Dr. em Zootecnia, Universidade Estadual Paulista, UNESP, Jaboticabal, SP, Brasil. E-mail: daniel.prd@hotmail.com

6 Prof ${ }^{a}$, Universidad del Tolima, UT, Ibagué, TOL, Colômbia. E-mail: linapenuela@gmail.com

7 Pós-Doutorado em Zootecnia, UNIOESTE, Marechal Cândido Rondon, PR, Brasil. E-mail: aparecidacostaoliveira@gmail.com

8 Prof $f^{a}$, UNIOESTE, Marechal Cândido Rondon, PR, Brasil. E-mail: silteixeira@gmail.com

9 Discente de Doutorado em Zootecnia, UNIOESTE, Marechal Cândido Rondon, PR, Brasil. E-mail: jansllerg@gmail.com

* Author for correspondence
} 
plasmáticos, desempenho zootécnico e a viabilidade econômica. No experimento I, realizou-se um ensaio de digestibilidade, utilizando 30 suínos machos castrados (14.4 $\pm 2.4 \mathrm{~kg}$ de peso corporal), distribuídos em um delineamento inteiramente casualizado. Os coprodutos estudados foram a quirera de arroz (QA) e o arroz canjica 3/4 (AC) em substituição à ração referência $(300 \mathrm{~g} / \mathrm{kg})$. Os valores estimados de energia digestível (ED) e energia metabolizável (EM) foram de 3.476 e $3.360 \mathrm{kcal} / \mathrm{kg}$ para QA e 3.487 e $3.362 \mathrm{kcal} / \mathrm{kg}$ para AC, respectivamente. No experimento II, foram utilizados 108 suínos $(15.5 \pm 1.0$ a $30.1 \pm 1.3 \mathrm{~kg}$ de peso corporal), distribuídos em um delineamento em blocos casualizados, em esquema de análise fatorial $(2 \times 4)$, com dois tipos de arroz e quatro níveis de inclusão $(160,320,480$ e $640 \mathrm{~g} / \mathrm{kg})$, com seis repetições e dois suínos por unidade experimental. Adicionalmente, foi utilizada uma ração controle, sem inclusão dos coprodutos. O ganho diário de peso aumentou e a conversão alimentar reduziu quando aumentou AC nas rações. Foi obtido efeito dos tipos de arroz sobre a concentração de glicose plasmática, em que os suínos alimentados com QA apresentaram os maiores valores. O custo de ração (CR) por quilograma de ganho de peso corporal aumentou em função dos níveis de QA. Observou-se que os níveis de 480 e $640 \mathrm{~g} / \mathrm{kg}$ de inclusão de QA diferiram da ração controle, apresentando os maiores custos. O AC e o QA podem ser utilizados, em dietas para suínos na fase inicial, em até o nível de $640 \mathrm{~g} / \mathrm{kg}$ sem prejudicar o desempenho.

Palavras-chave: Coproduto. Digestibilidade. Desempenho zootécnico. Suínos.

\section{Introduction}

Pig feed represents approximately $60 \%$ of production costs. One of the main aspects that influence the cost of production is fluctuation in the price of ingredients. Therefore, some studies have been conducted with new ingredients to determine their nutritional value, the biological response and the economic feasibility of their inclusion in the diets. Agrobusiness co-products have the potential for use in animal feed (VOLPATO et al., 2015).

Thus, the need arises for, and it becomes indispensable to the production of pigs, the study of new foods and nutritional strategies that contribute to the better metabolic functioning of the animals. The use of rice co-products deserves attention because it is a staple cereal grain for human consumption and is cultivated in most tropical and semi-tropical regions (CHE et al., 2012).

Rice production in Brazil during the 2015/2016 harvest was 11 million tons, with the southern region as the main producer, making Brazil the lead producer among non-Asian countries (FAO, 2017). Of the total production, about $60-72 \%$ of rice grain is used as polished rice for human consumption and the remaining co-products from the rice milling industry, including rice hulls, rice bran, broken rice and rice mill feed (28-35\%), may be used in animal feed (SINGH et al., 2013).

Rice co-products used in animal feed include broken rice (BR) obtained during the screening process, which consists of broken and malformed grains and corresponds to $14 \%$ of the total grain (LIMBERGER, 2008). Broken rice has been used as a great alternative to corn in animal feed (NEPOMUCENO et al, 2011; CHE et al., 2012) due to its similar metabolisable energy and crude protein values. However, BR has a lower fat content and higher starch content than corn (ROSTAGNO et al., 2017) and contains a very low concentration of fibre (CHE et al., 2012). Some advantages of replacing corn with rice co-products relate to the low levels of mycotoxins in the grain, because corn is affected by high contamination, mainly with aflatoxin (BUTOLO, 2010).

Rice and corn co-products have shown similar effects on animal performance, but rice may induce a prebiotic effect and increased serum concentrations of IgA, indicating an improved immune response (HENDERSON et al., 2012), without effect of inclusion of defatted rice bran on concentration of peptide YY (PYY), indicating that the energy status of the pigs was not changed (CASAS; STEIN, 2016a). In addition, the tendency for decreasing 
concentrations of TNF- $\alpha$ in plasma observed in pigs fed diets with increasing concentrations of full-fat rice bran (FFRB) indicates a potential for reducing inflammatory responses in the intestine (CASAS; STEIN, 2016a). The scientific literature contains few studies of rice co-products and the response of blood parameters, such as glucose, triglycerides, cholesterol and plasma urea nitrogen.

Gomes et al. (2012) found that the inclusion of up to $200 \mathrm{~g} / \mathrm{kg}$ of rice bran in pig diets after weaning did not impair performance and was proven to be economically viable. Similar performance was observed when replacing corn with rice in piglet feed (CHE et al., 2012). Likewise, inclusion of 10\% stabilised FFRB improved feed efficiency and increased the concentration of colonic bifidobacteria in weanling piglets, indicating that stabilised FFRB also may have prebiotic properties (HERFEL et al., 2013). However, depending on the type of soil in which rice is cultivated and the kind of processing to which it is submitted, these co-products may show variability in chemical composition. This prompts the need to conduct studies to determine the nutritional value of such products and their effects on animal performance and production cost.

Therefore, the objective of this experiment was to evaluate the inclusion of two rice co-products in the pig feed during the starter phase, specifically the nutritional value and digestibility of the coproducts, and effects on plasma parameters, growth performance and economic viability.

\section{Materials and Methods}

\section{Experimental design, animals, housing and diets}

The experiments were carried out at the Swine Experimental Unit at Iguatemi's Farm, which belongs to the Agricultural Sciences Center from Universidade Estadual de Maringá, in the state of Paraná $\left(23^{\circ} 25^{\prime} \mathrm{S}, 51^{\circ} 57^{\prime} \mathrm{O}\right.$, altitude $\left.550 \mathrm{~m}\right)$.

Two rice co-products (broken rice - $\mathrm{BR}$ and hominy rice $3 / 4$ - HC) were used. Both were ground in a hammer mill type, with a $2 \mathrm{~mm}$ sieve. To determine the chemical and energy composition of the co-products, analysis was performed in the Food and Animal Nutrition Analysis Laboratory at Universidade Estadual de Maringá, as described by Silva and Queiroz (2002), and the gross energy values were determined using a adiabatic calorimeter (Parr Instrumen Co. AC720). The amino acid composition of $\mathrm{BR}$ and $\mathrm{HC}$ co-products was determined in the Laboratory Evonik Industries using NIRs method.

A digestibility assay (Experiment I) was conducted using 30 crossbred barrows of commercial lines, averaging $14.4 \pm 2.4 \mathrm{~kg}$ body weight and distributed in a completely randomised design. The pigs were individually allotted in metabolism cages, similar to those described by Pekas (1968).

The co-products (BR and HR) replaced $300 \mathrm{~g} /$ $\mathrm{kg}$ of the basal diet (BD) based on dry matter. This resulted in two test diets (DT) and one reference diet (RD), which were based on corn and soybean meal and formulated to meet the requirements proposed by Rostagno et al. (2011).

The experimental period was 16 days, including 11 days for adaptation to feed and cages and 5 days for total faeces and urine collection. Feeding and total faeces and urine collection were performed as described by Sakomura and Rostagno (2016). The feed provided in the collection period was calculated according to the average consumption recorded in the adaptation period, based on metabolic weight $\left(\mathrm{kg}^{0.75}\right)$ of each pig. The total feed intake, determined for each animal, was divided into two meals, with $55 \%$ the total in the morning feed $(08 \mathrm{~h} 30)$ and $45 \%$ in the afternoon feed (14h00), moistened with $20 \%$ water to prevent waste, improve acceptance of the feed and reduce dustiness. Water was provided after each meal, based on a proportion of $3 \mathrm{ml}$ of water per $\mathrm{g}$ of feed, to prevent excessive consumption of water which could interfere with feed intake.

To mark the beginning and the end of the faeces collection period, $2 \%$ of ferric oxide $\left(\mathrm{Fe}_{2} \mathrm{O}_{3}\right)$ was 
added to the feed as a faecal marker. Once a day, faeces were packed in plastic bags and stored in a freezer $\left(-18{ }^{\circ} \mathrm{C}\right)$. Subsequently, faeces were homogenised, samples dried at $55^{\circ} \mathrm{C}$ and ground in a knife type mill $(1 \mathrm{~mm})$ for analysis. Urine was collected daily in individual plastic buckets containing $20 \mathrm{ml}$ of $\mathrm{HCl}$ solution (1:1). A rate of $20 \%$ was removed daily and frozen at $-18^{\circ} \mathrm{C}$; this was homogenised at the end of the experiment to determine gross energy.

A growth performance study (Experiment II) was conducted, involving 108 pigs (54 barrows and
54 gilts) from a commercial line, averaging 15.5 $\pm 1.0 \mathrm{~kg}$ live weight. These were allotted to eight treatments in a completely randomised block design, with six replications per treatment. Treatments were arranged as a $2 \times 4$ factorial, two types of broken rice (BR and HR) and four inclusion levels of each rice $(160,320,480$ and $640 \mathrm{~g} / \mathrm{kg})$. Additionally, a control diet $(0 \mathrm{~g} / \mathrm{kg})$ was formulated. Formulated diets were based on corn and soybean meal (Table 1) to meet the requirements proposed by Rostagno et al. (2011), which were based on a high potential meat deposition in the carcass genotype.

Table 1. Chemical and energetic composition, and cost of diets with inclusion levels of rice co-products (broken rice - BR and hominy rice - HR) in starting pigs feeding (15 to $30 \mathrm{~kg}$ ).

\begin{tabular}{|c|c|c|c|c|c|c|c|c|c|}
\hline \multirow{2}{*}{ Item $\mathrm{g} / \mathrm{kg}$} & \multirow[b]{2}{*}{ Control } & \multicolumn{4}{|c|}{ BR $\mathrm{g} / \mathrm{kg}$} & \multicolumn{4}{|c|}{$\mathrm{HR} \mathrm{g} / \mathrm{kg}$} \\
\hline & & 160 & 320 & 480 & 640 & 160 & 320 & 480 & 640 \\
\hline Corn & 636.4 & 473.4 & 310.5 & 147.6 & - & 470.9 & 305.5 & 140.0 & - \\
\hline Rice co-product & - & 160.0 & 320.0 & 480.0 & 640.0 & 160.0 & 320.0 & 480.0 & 640.0 \\
\hline Soybean meal & 324.8 & 328.4 & 332.0 & 335.6 & 323.3 & 330.9 & 336.9 & 343.0 & 322.8 \\
\hline Soybean Oil & 6.910 & 6.510 & 6.11 & 5.710 & 4.810 & 6.520 & 6.130 & 5.740 & 4.520 \\
\hline Limestone & 7.480 & 7.390 & 7.30 & 7.210 & 7.120 & 7.370 & 7.250 & 7.130 & 7.030 \\
\hline Dicalcium Phosphate & 13.51 & 13.70 & 13.88 & 14.07 & 14.42 & 13.74 & 13.97 & 14.19 & 14.71 \\
\hline Salt & 4.000 & 4.000 & 4.00 & 4.000 & 4.000 & 4.000 & 4.000 & 4.000 & 4.000 \\
\hline Vitamin-trace mineral premix ${ }^{1}$ & 5.000 & 5.000 & 5.00 & 5.000 & 5.000 & 5.000 & 5.000 & 5.000 & 0.500 \\
\hline Antibiotic $^{2}$ & 0.100 & 0.10 & 0.10 & 0.100 & 0.100 & 0.100 & 0.100 & 0.100 & 0.100 \\
\hline L-Lysine HCL & 1.420 & 1.17 & 0.91 & 0.660 & 0.890 & 1.150 & 0.890 & 0.620 & 0.115 \\
\hline DL-Methionine & 0.360 & 0.28 & 0.20 & 0.110 & 0.180 & 0.310 & 0.250 & 0.190 & 0.380 \\
\hline L-Threonine & - & - & - & - & 0.220 & - & - & - & 0.360 \\
\hline \multicolumn{10}{|c|}{ Calculated composition ( $\mathrm{g} / \mathrm{kg}$ unless indicated otherwise $)^{3}$} \\
\hline Metabolizable energy, Kcal/kg & 3,230 & 3,230 & 3,230 & 3,230 & 3,230 & 3,230 & 3,230 & 3,230 & 3,230 \\
\hline Crude protein & 197.0 & 199.4 & 201.7 & 204.0 & 201.0 & 198.9 & 200.7 & 202.6 & 195.4 \\
\hline Calcium & 7.33 & 7.33 & 7.33 & 7.33 & 7.33 & 7.33 & 7.33 & 7.33 & 7.33 \\
\hline Digestible Phosphorus & 3.63 & 3.63 & 3.63 & 3.63 & 3.63 & 3.63 & 3.63 & 3.63 & 3.63 \\
\hline Digestible lysine & 10.37 & 10.37 & 10.37 & 10.37 & 10.37 & 10.37 & 10.37 & 10.37 & 10.37 \\
\hline Digestible Met.+cyst & 5.81 & 5.81 & 5.81 & 5.81 & 5.81 & 5.81 & 5.81 & 5.81 & 5.81 \\
\hline Digestible threonine & 6.53 & 6.53 & 6.53 & 6.53 & 6.53 & 6.53 & 6.53 & 6.53 & 6.53 \\
\hline Cost of diet, $\mathrm{R} \$ / \mathrm{kg}^{4}$ & 0.635 & 0.702 & 0.768 & 0.834 & 0.898 & 0.703 & 0.771 & 0.838 & 0.902 \\
\hline
\end{tabular}

${ }^{1}$ Vitamin-trace mineral premix (provided per kg of diet); ${ }^{2}$ Antibiotic: Leucomag (Ceva Animal Health, Paulínia, Brazil); ${ }^{3}$ Based on the feed composition proposed by Rostagno et al. (2011) and/or estimated; ${ }^{4}$ Cost obtained in February 2013 in the state of Parana/ Brazil.

Sample collection and preparation

The digestibility coefficients of dry matter (DCDM), organic matter (DCOM), gross energy
(DCGE), starch (DCS) and the gross energy metabolisability (MCGE) of BR and HR were calculated according to the equations proposed by Matterson et al. (1965). 
The chemical composition and metabolisable energy values of $\mathrm{BR}$ and $\mathrm{HR}$ (Trial I) were considered in the formulation of diets. In the case of other ingredients (corn and soybean meal), CP, GE, $\mathrm{P}$ and $\mathrm{Ca}$ were analysed and applied the digestibility coefficients, as recommended by Rostagno et al. (2011).

At the end of the study, body weight (BW) and feed intake were recorded and average daily gain (ADG), average daily feed intake (ADFI) and feed:gain $(F: G)$ of each experimental unit were calculated.

Blood samples were collected from the cranial vena cava. All blood samples were transferred into glass tubes containing heparin, with the exception of samples for plasma glucose analysis which were transferred into glass tubes containing sodium fluoride + potassium oxalate. After sampling, blood was centrifuged at $3000 \times g$ for $15 \mathrm{~min}$ at room temperature to obtain the plasma; this was placed in propylene microtubes and stored $\left(-18{ }^{\circ} \mathrm{C}\right)$ for subsequent analyses. For biochemical analysis (cholesterol, glucose, triglycerides and plasma urea nitrogen - PUN) commercial kits were used (Gold Analisa Diagnóstica Ltda.), and the amount of each blood component was determined by a spectrophotometer (BIOPLUS 2000; Bioplus, Barueri, SP, Brazil).

\section{Statistical analysis and economic feasibility}

To evaluate the economic feasibility of including $\mathrm{BR}$ and $\mathrm{HR}$ in pig diets, the raw material prices were quoted for the region of Maringá in 2012 as follows: soybean meal, R\$ 0.810/kg; corn, R\$ 0.417/kg; soybean oil R\$3.00/kg; dicalcium phosphate, R\$ 1,900/kg; limestone, R\$ 0.280; L-Lys, R \$ 4,920/kg; DL-Met, R\$ 9,124/kg; L-Thr, R\$ 6,262/kg; vitamintrace mineral premix R\$7,360/kg; salt R\$0352/kg; leucomag, R\$ 96,000/kg; and BR and HR, R \$ 0.840/ $\mathrm{kg}$. The feed cost per kilogram of body weight gain was then calculated, as proposed by Bellaver et al. (1985), as follows: $\mathrm{Y} i(\mathrm{R} \$ / \mathrm{kg})=\mathrm{Q} i \times \mathrm{P} i / \mathrm{G} i$ where
$\mathrm{Y} i=$ feed cost per $\mathrm{kg}$ live weight gain in the $i$-nth treatment; Q $i=\mathrm{DFI}$ in the $i$-nth treatment; $\mathrm{P} i=$ cost of $\mathrm{kg}$ of feed in the $i$-nth treatment and $\mathrm{G} i=\mathrm{ADG}$ of $i$-nth treatment.

The Index of Economic Efficiency (IEE) and the Cost Index (CI) were calculated as proposed by Gomes et al. (1991), as follows: IEE (\%) = MCe/ $\mathrm{CTei} \times 100$ and $\mathrm{CI}(\%)=\mathrm{CTei} / \mathrm{MCe} \times 100$ where $\mathrm{MCe}=$ lower feed cost per $\mathrm{kg}$ of GDP observed between treatments and Ctei $=$ cost of treatment $i$.

To assess the differences between the digestibility coefficients of BR and HR, the data were submitted to analysis of variance, using the following statistical model: $\mathrm{Y}_{\mathrm{ij}}=\mu+\mathrm{T}_{\mathrm{i}}+\mathrm{e}_{\mathrm{ij}}$. The effects of the factors included in the model are represented by: $\mathrm{Y}_{\mathrm{ij}}=$ digestibility coefficients of the treatment $i$, of the replication $j ; \mu=$ constant associated with all observations; $\mathrm{T}_{\mathrm{i}}=$ effect of food type $i$, for $i=1 ; 2(1=\mathrm{BR}$ and $2=\mathrm{HR})$; and $\mathrm{e}_{\mathrm{ij}}$ $=$ random error associated with each observation. Additionally, for the performance characteristics, the data were submitted to analysis of variance and the statistical model used was: $\mathrm{Y}_{\mathrm{ijk}}=\mu+\mathrm{B}_{\mathrm{i}}+\mathrm{N}_{\mathrm{j}}+$ $\mathrm{F}_{\mathrm{k}}+\mathrm{NF}_{\mathrm{jk}}+\mathrm{e}_{\mathrm{ijkl}}$. The effects of the factors included in the model are represented by: $\mathrm{Y}_{\mathrm{ijkl}}=$ observation of animal 1, within block $i$, level of inclusion $j$ and type of rice broken $k ; \mu=$ constant associated with all observations; $\mathrm{B} i=$ effect of block, for $i=$ $1,2, \ldots ., 6 ; \mathrm{N} j=$ effect of BR and HR levels, for $j$ $=160,320,480$ and $640 \mathrm{~g} / \mathrm{kg} ; \mathrm{F}_{\mathrm{k}}=$ effect of rice type, for $k=\mathrm{BR}$ and $\mathrm{HR} ; \mathrm{NF}_{\mathrm{jk}}=$ effect of interaction of inclusion levels $j$ and type of broken rice $k$; $\mathrm{e}_{\mathrm{ijkl}}$ $=$ random error associated with each observation. For the biochemical blood variables, the initial body weight was used as a covariate. For the economic feasibility, the Dunnett test (SAMPAIO, 1998) was used to compare the feed cost (FC) per $\mathrm{kg} / \mathrm{BW}$ gain $(\mathrm{FC}, \mathrm{R} \$ / \mathrm{kg} \mathrm{BW})$ of the test diet $(0 \%$ broken rice) with each inclusion level of $\mathrm{BR}$ and HR. Statistical analysis was performed using the Sistema de Análises Estatísticas e Genéticas SAEG (Universidade Federal de Viçosa, Viçosa, MG, Brazil). 


\section{Results and Discussion}

\section{Digestibility assay}

No health problems were recorded during the experimental period. The minimum and maximum temperatures recorded during the digestibility assay were $24.05 \pm 1.09{ }^{\circ} \mathrm{C}$ and $25.21 \pm 0.87^{\circ} \mathrm{C}$, respectively.

The chemical composition (Table 2) of rice coproducts for dry matter (DM) values are different from those observed by Casas and Stein (2015) and
Menoyo et al. (2011) who reported 881 and $905 \mathrm{~g} /$ $\mathrm{kg}$, respectively. The variation in the DM content may be attributed to the type of industrial process that the rice underwent. The $\mathrm{CP}$ values obtained for BR and HR were 80.8 and $71 \mathrm{~g} / \mathrm{kg}$, respectively. Broken rice showed a higher concentration of $\mathrm{CP}$ $(121 \mathrm{~g} / \mathrm{kg})$ compared to HR. These results were similar to those obtained by Nepomuceno et al. (2011), Che et al. (2012) and Solà-Oriol et al. (2009), who reported CP content of 85, 74 and $71 \mathrm{~g} /$ $\mathrm{kg}$ for BR, respectively.

Table 2. Chemical and energetic composition of rice co-products (natural matter).

\begin{tabular}{lcc}
\hline Item, $\mathrm{g} / \mathrm{kg}^{1}$ & Broken rice & Hominy Rice \\
\hline Gross energy, kcal/kg & 3,921 & 3,818 \\
Dry matter & 889.0 & 892.2 \\
Crude protein & 80.8 & 71.0 \\
Starch & 70,30 & 72,07 \\
Ether extract & 13.2 & 6.2 \\
Mineral matter & 9.7 & 5.6 \\
Ca & 0.2 & 0.1 \\
Total phosphorus & 2.1 & 1.4 \\
Available phosphorus & 0.02 & 0.20 \\
Total carbohydrates & 896.3 & 917.2 \\
Non-fibrous carbohydrates & 884.7 & 908.5 \\
Lysine $^{2}$ & 3.0 & 2.6 \\
Methionine $^{2}$ & 2.2 & 2.0 \\
Threonine $^{2}$ & 2.8 & 2.5 \\
\hline
\end{tabular}

${ }^{1}$ - Analysis performed in the Animal Nutrition Laboratory of the State University of Maringa - UEM; ${ }^{2}$ - Analysis performed in the Evonik Industries.

The amounts of amino acids in BR and HR were similar to those reported by Rostagno et al. (2017) and NRC (2012). However, Brestenský et al. (2013), using BR in piglet feed, found lower values for Met $(1.8 \mathrm{~g} / \mathrm{kg})$, higher for Thr $(4.4 \mathrm{~g} /$ $\mathrm{kg}$ ) and similar for Lys $(3.0 \mathrm{~g} / \mathrm{kg})$. Some of these factors may be related to differences in the amino acid composition of the co-products evaluated, such as culture variety, culture condition and quantity of waste (for example, presence of weed seeds).

In relation to the total carbohydrate content, the values were $896 \mathrm{~g} / \mathrm{kg}$ for BR and $917 \mathrm{~g} / \mathrm{kg}$ for HR, of which $890 \mathrm{~g} / \mathrm{kg}$ were non-fibrous carbohydrates, indicating that the rice grains are characterised by a high starch content and low amount of non-starch polysaccharide. Most of this starch is in free form, facilitating digestibility and utilisation by the pig (CARCIOFI et al., 2008).

It is also possible that the co-products sometimes include other fractions of rice than just the bran, depending on the quality of the milling process and because of the large variation in the phytate concentration among different rice fractions, and this may influence the digestibility (CASAS; STEIN, 2015). 
The gross energy in food is provided by the feed combustion process of the component ingredients; however, some molecules produce more heat (EE and starch) than others (CP and CF). The difference in GE values between $\mathrm{BR}(3,921 \mathrm{kcal} / \mathrm{kg})$ and $\mathrm{HR}$ $(3,818 \mathrm{kcal} / \mathrm{kg})$ could be explained by their different EE values. It is known that the EE content of feed is positively correlated with the GE concentration. Therefore, the higher EE value, the higher will be the GE value (VOLPATO et al., 2015).

According to Casas and Stein (2016a), variation in the composition of these co-products may be a result of differences among rice mills in the milling process, resulting in varying fractions of the hulls and the starch being included in the rice bran.

Considering the digestibility coefficients and digestible nutrients (Table 3), we can infer that these co-products are a good source of energy for pigs (15 to $30 \mathrm{~kg} \mathrm{BW}$ ). By comparing the results obtained for DE and ME in this study with the values reported by Rostagno et al. (2017), there were lower values for both co-products $(3,572$ and $3,489 \mathrm{kcal} / \mathrm{kg}$, respectively). High ME:DE ratios are due to the high metabolism of co-products, which translates into a low excretion rate via urine.

Table 3. Apparent digestibility coefficients (DC), metabolizability coefficient (MC) and digestible nutrients of two rice co-products ${ }^{1}$.

\begin{tabular}{lcc}
\hline Digestibility, $\mathrm{g} / \mathrm{kg}$ & Broken rice & Hominy rice \\
\hline DC of dry matter & 853.3 & 846.6 \\
DC of organic matter & 979.3 & 979.7 \\
DC of starch & 999.7 & 1001.0 \\
DC of gross energy & 886.3 & 913.2 \\
MC of gross energy & 856.8 & 880.5 \\
Digestible Nutrients ${ }^{1}$ & & \\
DMD, \% & 764.5 & 757.6 \\
OMD, \% & 868.9 & 871.8 \\
Starch D, \% & 702.8 & 721.4 \\
DE, $\mathrm{kcal} / \mathrm{kg}$ & 3476 & 3487 \\
ME, kcal/kg & 3360 & 3362 \\
ME: $\mathrm{DE}$ & 0.97 & 0.96 \\
\hline
\end{tabular}

${ }^{1-}$ Based on natural matter.

Menoyo et al. (2011) observed high values for DCOM (86\%), DCS (90\%) and DCGE (84\%) when evaluating the digestibility of rice bran for piglets. In addition, the authors found that starch digestibility was better for rice bran than for corn. The higher digestibility values for rice co-products can be explained by the different starch content of the grains; the greater starch availability in rice grain than in corn grain, together with the smaller size of the rice grain, allows greater activity by the digestive enzymes (SVIHUS et al., 2005).

Rice is characterised by a high starch content and low fibre content; therefore, it can have a major impact on the digestibility of dietary nutrients (CHE et al., 2012).

\section{Growth performance}

An interaction was demonstrated $(\mathrm{P}<0.05)$ between rice co-products and its inclusion levels (Table 4), indicating a different effect for each studied co-product. A linear effect $(\mathrm{P}<0.05)$ of HR levels on ADG and F:G was observed. The increase in $\mathrm{ADG}$ and improved $\mathrm{F}: \mathrm{G}$ observed in 
pigs receiving diets containing $\mathrm{HR}$ may be due to the high starch content, since this represented $72 \%$ of the co-product composition. The greater G:F observed in pigs fed diets containing FFRB compared with defatted rice bran is also a consequence of the greater metabolisable energy in FFRB compared with DFRB (CASAS; STEIN, 2016b). When we consider the efficiency of starch use, it is an excellent energy source. Van Milgen et al. (2001) determined that the energy efficiency of starch $(842 \mathrm{~g} / \mathrm{kg})$ and $\mathrm{EE}(883 \mathrm{~g} / \mathrm{kg})$ was higher than the CP $(520 \mathrm{~g} / \mathrm{kg})$.

Table 4. Average daily feed intake (ADFI), average daily gain (ADG) and gain:feed (F:G) of pigs feeding diets with inclusion levels of rice co-products.

\begin{tabular}{|c|c|c|c|c|c|c|c|c|c|c|c|c|c|c|}
\hline & & \multicolumn{4}{|c|}{$\mathrm{BR} \mathrm{g} / \mathrm{kg}$} & \multicolumn{4}{|c|}{$\mathrm{HR} \mathrm{g} / \mathrm{kg}$} & \multirow{2}{*}{ SEM $^{1}$} & \multirow{2}{*}{$\mathrm{RB}^{*} \mathrm{NV}^{3}$} & \multirow{2}{*}{$\mathrm{RB}^{2}$} & & \multirow{2}{*}{$2^{5}$} \\
\hline Item & Control & 160 & 320 & 480 & 640 & 160 & 320 & 480 & 640 & & & & & \\
\hline ADFI, kg & 1.202 & 1.256 & 1.259 & 1.284 & 1.323 & 1.207 & 1.272 & 1.318 & 1.353 & 1.284 & NS & NS & NS & NS \\
\hline $\mathrm{ADG}, \mathrm{kg}$ & 0.576 & 0.659 & 0.639 & 0.626 & 0.689 & 0.544 & 0.624 & 0.674 & 0.742 & 0.650 & 0.01 & NS & $\operatorname{HR}(0.01)$ & NS \\
\hline$F: G$ & 2.128 & 1.930 & 1.970 & 2.060 & 1.940 & 2.250 & 2.050 & 1.960 & 1.820 & 2.000 & 0.01 & NS & $\operatorname{HR}(0.03)$ & NS \\
\hline
\end{tabular}

${ }^{1}$ Standard error of the means; ${ }^{2}$ Rice co-products; ${ }^{3}$ Interaction between RB and inclusion levels; ${ }^{4}$ Linear effect of inclusion levels of RB (HR: ADG: 0.485323 + 0.00401600X; F:G: 2.36308 - 0.00858591X); ${ }^{5}$ Quadratic effect of RB; NS = non-significant.

It is also possible that because the co-products contain lower levels of soluble non-starch polysaccharides, which decrease the viscosity of digesta, this results in a lower incidence of diarrhoea and lower proliferation of potential harmful bacteria.

Considering the performance variables, we found that rice co-products did not impair performance of pigs. Similar results have been reported by Li et al. (2006) and Nepomuceno et al. (2011). Replacing corn with rice $(0,500,750$ and $1000 \mathrm{~g} / \mathrm{kg}$ of BR) in piglet feed (from 0 to 42 days post-weaning), Che et al. (2012) found no differences in animal performance, concluding that $\mathrm{BR}$ can replace corn at up to $1000 \mathrm{~g} / \mathrm{kg}$ of diet. On the other hand, Menoyo et al. (2011), in an evaluation of BR (Raw, $1000 \mathrm{~g} / \mathrm{kg}$ ) or BR (thermal processing, $1000 \mathrm{~g} / \mathrm{kg}$ ) compared to corn grain in weaned pigs, observed no differences in performance variables. According to Che et al. (2012), rice can substitute for corn in diets of nursery pigs without detrimental effects on growth performance. Results of previous studies have indicated that rice bran may improve health status of the animal and favours positive results in growth performance.

\section{Blood biochemical parameters}

Regarding the blood biochemical parameters (Table 5), the results showed that the type of rice co-product affected $(\mathrm{P}<0.05)$ plasma glucose levels, in which the diet containing BR produced a higher value $(6.8 \%)$ than the diet containing HR. The values reported are close to the specified range of 65 to 106 $\mathrm{mg} / \mathrm{dL}$ for glucose (ELITech kits) and specified range of 65 to $99 \mathrm{mg} / \mathrm{dL}$ (Gold Analisa Diagnóstica Ltda). For serum parameters of cholesterol, triglycerides and PUN, no effect $(\mathrm{P}>0.05)$ was observed and the lack of difference between treatments indicates that $\mathrm{BR}$ and HR did not change plasma concentration of these parameters. 
Table 5. Plasma levels ( $\mathrm{mg} / \mathrm{dL}$ ) of glucose, triglycerides, cholesterol and plasma urea nitrogen (PUN) of pigs, feeding diets with inclusion levels of broken rice (BR) and hominy rice (HR).

\begin{tabular}{|c|c|c|c|c|c|c|c|c|c|c|c|c|c|c|}
\hline \multirow{2}{*}{ Item } & \multicolumn{5}{|c|}{$\mathrm{BR} \mathrm{g} / \mathrm{kg}$} & \multicolumn{4}{|c|}{$\mathrm{HR} \mathrm{g} / \mathrm{kg}$} & \multirow[b]{2}{*}{ SEM $^{1}$} & \multirow[b]{2}{*}{$\mathrm{RB}^{2}$} & \multirow[b]{2}{*}{$\mathrm{RBxNV}$} & \multirow[b]{2}{*}{$\mathrm{L}^{3}$} & \multirow[b]{2}{*}{$\mathrm{Q}^{4}$} \\
\hline & Control & 160 & 320 & 480 & 640 & 160 & 320 & 480 & 640 & & & & & \\
\hline Glucose & 78.39 & 79.92 & 88.21 & 83.00 & 86.43 & 78.07 & 73.07 & 79.18 & 84.28 & 81.17 & 0.01 & NS & NS & NS \\
\hline Triglycerides & 55.90 & 48.32 & 51.08 & 49.33 & 45.08 & 53.24 & 41.68 & 47.14 & 38.95 & 47.86 & NS & NS & NS & NS \\
\hline Cholesterol & 64.12 & 56.82 & 60.14 & 56.21 & 65.25 & 57.14 & 59.10 & 59.61 & 60.52 & 59.88 & NS & NS & NS & NS \\
\hline PUN & 13.86 & 15.17 & 14.48 & 17.08 & 16.67 & 13.08 & 13.91 & 16.13 & 14.18 & 14.95 & NS & NS & NS & NS \\
\hline
\end{tabular}

${ }^{1}$ Standard error of the means.

${ }^{2-}$ Rice co-products.

${ }^{3-}$ Linear effect of inclusion levels of RB.

4- Quadratic effect of inclusion levels of RB.

Due to efficient homeostatic mechanisms, blood glucose levels do not vary significantly. Thus, the glycemic level is not directly affected by diet due to homeostatic mechanisms, except in animals with advanced malnutrition (GONZÁLEZ; SCHEFFER, 2002). We found no plausible explanation for the higher glucose values with the diet containing BR.

The efficiency of nitrogen utilisation in pigs may be estimated by measuring blood urea nitrogen (BUN). However, the reduction in BUN also indicates that amino acids were better utilised and there was less deamination of amino acids.

Pigs that received BR and $\mathrm{HR}$ in the diet at up to $640 \mathrm{~g} / \mathrm{kg}$ had higher plasma glucose levels (10.2 and $7.5 \%$, respectively) than the control diet. This may be related to the starch content of co-products, since these have approximately $16 \%$ more starch than corn. It is known that the amount and type of starch are among the main factors that affect blood sugar levels (BASSO et al., 2011).

Considering the plasma glucose levels, the difference between the co-products may be due to the variations in processing and the degree of polishing that occurs, which may alter nutrient concentrations (WALTER et al., 2008). Another aspect related to BR is the amylose:amylopectin ratio. Starchy products, such as rice, that have a high amylose content have a lower glycaemic response (GODDARD et al., 1984) and this relationship may explain the differences between the rice coproducts.

\section{Economic analysis}

The economic analysis showed that FC per kilogram of body weight gain increased linearly $(\mathrm{P}<0.05)$ as BR levels increased (Table 6). The Dunnett test showed that levels of BR at 480 and $640 \mathrm{~g} / \mathrm{kg}$ were different from the control diet and showed the highest FC. However, the feasibility of using BR will depend on the differences in price of the other raw materials used in feed formulation.

In the case of HR, considering the regression analysis, there was no difference in the FC/ $\mathrm{kg}$ body weight gain $(\mathrm{P}>0.05)$ and HR may be included in the diet at up to $640 \mathrm{~g} / \mathrm{kg}$ for pigs from 15 to 30 $\mathrm{kg}$ body weight. In this sense, replacing corn by processed rice co-products can be economically viable, once they are available. 
Table 6. Economic feasibility of inclusion levels of broken rice (BR) and hominy rice (HR) in diets for pigs from 15 to $30 \mathrm{~kg}$ body weight.

\begin{tabular}{|c|c|c|c|c|c|c|c|c|}
\hline \multicolumn{9}{|c|}{ Rice co-products g/kg } \\
\hline Item & Control & 160 & 320 & 480 & 640 & SEM $^{1}$ & Dun $^{2}$ & $\operatorname{Reg}^{3}$ \\
\hline \multicolumn{9}{|c|}{ BR } \\
\hline Initial BW, kg & 15.48 & 15.46 & 15.54 & 15.44 & 15.50 & \multirow{6}{*}{10.17} & \multirow{6}{*}{0.01} & \multirow{6}{*}{$\mathrm{L}: 0.01$} \\
\hline Final BW, kg & 28.43 & 31.84 & 29.97 & 29.52 & 31.00 & & & \\
\hline Diet cost & 0.635 & 0.702 & 0.768 & 0.834 & 0.898 & & & \\
\hline $\mathrm{CR}, \mathrm{R} \$ / \mathrm{kg} \mathrm{BW}^{4}$ & 2.705 & 2.477 & 3.035 & $3.426^{*}$ & $3.457^{*}$ & & & \\
\hline $\mathrm{IEE}^{5}$ & 91.60 & 100.00 & 81.64 & 72.32 & 71.64 & & & \\
\hline $\mathrm{CI}^{6}$ & 109.17 & 100.00 & 122.48 & 138.27 & 139.59 & & & \\
\hline \multicolumn{9}{|c|}{ HR } \\
\hline Initial BW, kg & 15.48 & 15.54 & 15.46 & 15.45 & 15.49 & & \multirow{6}{*}{ NS } & \multirow{6}{*}{ NS } \\
\hline Final BW, kg & 28.43 & 27.74 & 29.45 & 30.59 & 32.17 & & & \\
\hline Diet cost & 0.635 & 0.703 & 0.771 & 0.838 & 0.902 & & & \\
\hline $\mathrm{CR}, \mathrm{R} \$ / \mathrm{kg} \mathrm{BW}$ & 2.705 & 3.163 & 3.159 & 3.277 & 3.274 & & & \\
\hline IEE & 91.60 & 99.87 & 100.00 & 96.41 & 96.50 & & & \\
\hline $\mathrm{CI}$ & 109.17 & 100.13 & 100.00 & 103.73 & 103.63 & & & \\
\hline
\end{tabular}

${ }^{1-}$ Standard error of the means; ${ }^{2-}$ Dunnett Test; *Value different $(\mathrm{P}<0.05)$ in relation to control diet, NS = non-significant;

${ }^{3-}$ Linear effect: QA = 2,26689 + 0,0207985x; ${ }^{4-} \mathrm{CR}, \mathrm{R} \$ / \mathrm{kg}$ PV: cost per kg of BW gain.; ${ }^{5}$ Index of economic efficiency;

${ }^{6}$ Cost index.

\section{Conclusions}

The estimated metabolisable energy values of BR and $\mathrm{HR}$ were 3,360 and $3,362 \mathrm{kcal} / \mathrm{kg}$, respectively. The co-product HR may be used for pigs from 15 to $30 \mathrm{~kg}$ body weight at up to $640 \mathrm{~g} / \mathrm{kg}$ of diet without changing the cost of the diet. However, its economic feasibility will depend on prices of the ingredients. Inclusion of BR at levels of 480 and $640 \mathrm{~g} / \mathrm{kg}$ increases the cost per kg body weight gain. The coproducts $\mathrm{HR}$ and BR can be used in pig feed during the starter phase at up to $640 \mathrm{~g} / \mathrm{kg}$ without impairing performance.

\section{References}

BASSO, C.; SILVA, L. P. D.; BENDER, A. B. B.; SILVEIRA, F. D. Elevação dos níveis de amido resistente: efeito sobre a glicemia e na aceitabilidade do alimento. Revista do Instituto Adolfo Lutz, São Paulo, v. 70, n. 3, p. 276-282, 2011.

BELlaVer, C.; FIALHO, E. T.; PROTAS, J. F. S.; GOMES, P. C. Radícula de malte na alimentação de suínos em crescimento e terminação. Pesquisa Agropecuária Brasileira, Brasília, v. 20, n. 8, p. 969-974, 1985.
BRESTENSKÝ, M.; NITRAYOVÁ, S.; PATRÁŠ, P.; HEGER, J. Standardized ileal digestibilities of amino acids and nitrogen in rye, barley, soybean meal, malt sprouts, sorghum, wheat germ and broken rice fed to growing pigs. Animal Feed Science and Technology, Amsterdam, v. 186, n. 1-2, p. 120-124, 2013.

BUTOLO, J.E. Qualidade de ingredientes na alimentação animal. $2^{\text {th }}$ ed. Botucatu: Faculty of Veterinary Medicine and Animal Science, UNESP, 2010. $430 \mathrm{p}$.

CARCIOFI, A. C. Protein and carbohydrate ingredients for dogs and cats. Revista Brasileira de Zootecnia, Viçosa, MG, v. 37, p. 28-41, 2008. Número Especial.

CASAS, G. A.; STEIN, H. H. Effects of full fat or defatted rice bran on growth performance and blood characteristics of weanling pigs. Journal of Animal Science, Champaign, v. 94, n. 10, p. 4179-4187, 2016a.

. Effects of microbial phytase on the apparent and standardized total tract digestibility of phosphorus in rice coproducts fed to growing pigs. Journal of Animal Science, Champaign, v. 93, n. 7, p. 3441-3448, 2015.

. Effects of microbial xylanase on digestibility of dry matter, organic matter, neutral detergent fiber, and energy and the concentrations of digestible and metabolizable energy in rice coproducts fed to weanling pigs. Journal of Animal Science, Champaign, v. 94, n. 5, p. 1933-1939, 2016 b. 
CHE, T. M.; PEREZ, V. G.; SONG, M.; PETTIGREW, J. E. Effect of rice and other cereal grains on growth performance, pig removal, and antibiotic treatment of weaned pigs under commercial conditions. Journal of Animal Science, Champaign, v. 90, n. 13, p. 4916-4924, 2012.

FOOD AND AGRICULTURE ORGANIZATION OF THE UNITED NATIONS - FAO. Rice around the world. Rome: FAO, 2017. Available at: <http://www.fao.org/ news/story/en/item/154122/icode/>. Accessed at: 10 june 2017.

GODDARD, M. S.; YOUNG, G.; MARCUS, R. The effect of amylose content on insulin and glucose responses to ingested rice. American Journal of Clinical Nutrition, Oxford, v. 39, n. 3, p. 388-392, 1984.

GOMES, M. F. M.; BARBOSA, H. P.; FERREIRA, A. S.; LIMA, G. M. M. de. Análise econômica da utilização do triguilho para suínos. Concórdia: EMBRAPACNPSA, 1991. 3 p. (EMBRAPA-CNPSA. Comunicado técnico, 179).

GOMES, T. R.; CARVALHO, L. E. de; FREITAS, E. R.; NEPOMUCENO, R. C.; ELLERY, E. A. C.; RUFINO, R. H. M. Efeito da inclusão de farelo de arroz integral em rações para leitões de 21 a 42 dias de idade. Archivos de Zootecnia, Córdoba, v. 61, n. 233, p. 129-139, 2012.

GONZÁLEZ, F. H. D.; SCHEFFER, J. F. S. Perfil sanguíneo: ferramenta de análise clínica, metabólica e nutricional. In: CONGRESSO NACIONAL DE MEDICINA VETERINÁRIA, 2002, Gramado. Anais... Porto Alegre: SBMV/SOVERGS, 2002. p. 5-17.

HENDERSON, A. J.; KUMAR, A.; BARNETT, B.; DOW, S. W.; RYAN, E. P. Consumption of rice bran increases mucosal immunoglobulin A concentrations and numbers of intestinal Lactobacillus spp. Journal of Medicinal Food, New Rochelle, v. 15, n. 5, p. 469-475, 2012.

HERFEL, T.; JACOBI, S.; LIN, X.; VAN HEUGTEN, E.; FELLNER, V.; ODLE, J. Stabilized rice bran improves weaning pig performance via a prebiotic mechanism. Journal of Animal Science, Champaign, v. 91, n. 2, p. 907-913, 2013.

LI, X.; YUAN, S. L.; PIAO, X. S.; LAI, C. H.; ZANG, J. J.; DING, Y. H.; HAN, L. J.; HAN, K. The nutritional value of brown rice and maize for growing pigs. AsianAustralasian Journal of Animal Sciences, Seoul, v. 19, n. 6, p. 892-897, 2006.

LIMBERGER, V. M.; SILVA, L. P.; EMANUELLI, T.; COMARELA, C. G.; PATIAS, L. D. Modificação química e física do amido de quirera de arroz para aproveitamento na indústria de alimentos. Química Nova, São Paulo, v.
31, n. 1, p. 84-88, 2008.

MATTERSON, L. D.; POTTER, L. M.; STUTZ, M. W.; SINGSEN, E. P. Research report 7: the metabolizable energy of feed ingredients for chickens. Hartford: Res. Rep. Conn. Agric. Exp. Stn., 1965. 11 p.

MENOYO, D.; SERRANO, M. P.; BARRIOS, V.; VALENCIA, D. G.; LÁZARO, R.; ARGENTE, J.; MATEOS, G. G. Cereal type and heat processing of the cereal affect nutrient digestibility and dynamics of serum insulin and ghrelin in weanling pigs. Journal of Animal Science, Champaign, v. 89, n. 9, p. 2793-2800, 2011.

NATIONAL RESEARCH COUNCIL - NRC. Nutrient requirements of swine. $11^{\text {th }}$ ed. Washington: National Academy Press, 2012.

NEPOMUCENO, R. C.; CARVALHO, L. E.; FREITAS, E. R.; GOMES, T. R.; AQUINO, T. M. F.; ELLERY, E. A. C.; MOREIRA, R. H. R.; VIEIRA, J. J. F. Inclusão da quirera de arroz em rações de suínos a fase de creche. Revista Brasileira de Saúde e Produção Animal, Salvador, v. 12, n. 3, p. 718-728, 2011.

PEKAS, J. C. Versatile swine laboratory apparatus for physiologic and metabolic studies. Journal of Animal Science, Champaign, v. 27, n. 5, p. 1303-1309, 1968.

ROSTAGNO, H. S.; ALBINO, L. F. T.; DONZELE, J. L.; GOMES, P. C.; OLIVEIRA, R. F.; LOPES, D. C.; FERREIRA, A. S.; BARRETO, S. L. T.; EUCLIDES, R. F. Brazilian tables for poultry and swine: composition of feedstuffs and nutritional requirements. $3^{\text {th }}$ ed. Viçosa, MG: UFV, 2011. 186 p.

ROSTAGNO, H. S.; ALBINO, L. F. T.; HANNAS, M.I.; DONZELE, J. L.; SAKOMURA, N. K.; PERAZZO, F. G.; SARAIVA, A.; TEIXEIRA, M. L.; RODRIGUES, P. B.; OLIVEIRA, R. F. de.; BARRETO, S. L. T.; BRITO, C. O. Brazilian tables for poultry and swine: composition of feedstuffs and nutritional requirements. $4^{\text {th }}$ ed. Viçosa, MG: UFV, 2017. 488 p.

SAKOMURA, N. K.; ROSTAGNO, H. S. Métodos de pesquisa em nutrição de monogástricos. $2^{\text {th }}$ ed. Jaboticabal: FUNEP, 2016. 262 p.

SAMPAIO, I. B. M. Estatística aplicada à experimentação animal. Belo Horizonte: Universidade Federal de Minas Gerais, 1998. 221 p.

SILVA, D. J.; QUEIROZ, A. C. Análise de alimentos: métodos químicos e biológicos. $3^{\text {th }}$ ed. Viçosa, MG: Universidade Federal de Viçosa, 2002. 235 p.

SINGH, A.; DAS, M.; BAL, S.; BANERJEE, R. 4 Rice processing. In: GUINE, R. P. F.; CORREIA, P. M. R. (Ed.). Engineering aspects of cereals and cereal based products. Boca Raton: CRC Press, 2013. p. 71-97. 
SOLÀ -ORIOL, D.; ROURA, E.; TORRALLARDONA, D. Feed preference in pigs: effect of cereal sources at different inclusion rates. Journal of Animal Science, Champaign, v. 87, n. 2, p. 562-570, 2009.

SVIHUS, B.; UHLEN, A. K.; HARSTAD, O. M. Effect of starch granule structure, associated components and processing on nutritive value of cereal starch: a review. Animal Feed Science and Technology, Amsterdam, v. 122, n. 3-4, p. 303-320, 2005.
VAN MILGEN, V.; NOBLET, J.; DUBOIS, S. Energetic efficiency of starch, protein and lipid utilization in growing pigs. The Journal of Nutrition, Philadelphia, v. 131, n. 14, p. 1309-1318, 2001.

VOLPATO, R. M.; OLIVEIRA, V.; GEWEHR, C. E.; PERES NETTO, D. Coprodutos da agroindústria na alimentação de leitões. Ciência Rural, Santa Maria, v. 45, n. 1, p. 86-91, 2015.

WALTER, M.; MARCHEZAN, E.; AVILA, L. A. Arroz: composição e características nutricionais. Ciência Rural, Santa Maria, v. 38, n. 4, p. 1184-1192, 2008. 